\title{
WOODY PLANTS AFFECTED BY UNGULATES IN WINTER PERIOD, IMPACTS AND BARK RENEWAL
}

\author{
MARTA NEVŘELOVÁ, JANA RUŽIČKOVÁ
}

Comenius University Bratislava, Faculty of Natural Sciences, Department of Environmental Ecology, Mlynská dolina, 84215 Bratislava, Slovak Republic; e-mail: jane.ruzickova@gmail.com

\begin{abstract}
Nevřelová M., Ružičková J.: Woody plants affected by ungulates in winter period, impacts and bark renewal. Ekológia (Bratislava), Vol. 34, No. 3, p. 235-248, 2015.

Due to biotope fragmentation and changes in landscape structure, opportunities for forest animals to migrate and obtain food are diminishing, especially during extreme winter conditions. The main objective of this research was an assessment of ungulates, impact on woody species, evaluation of damage forms and bark renewal phases of affected woody plants. The study area is located in western Slovakia in the southeast part of Malé Karpaty Mts. After the very cold and long winter of $2012 / 2013,34 \%$ of woody plants were damaged by bark stripping and biting on the forest locality and $53 \%$ of evaluated trees and shrubs were damaged by biting off shoots in the non-forest locality. Together, 262 woody plants belonging to 15 species were evaluated; the girth of tree trunks and stripped bark patches were measured. The most severely affected tree species, suffering from bark stripping and bitten-off sprouts, was Fraxinus excelsior; Acer campestre was also significantly affected. Results showed that woody plants provide a significant part of hoofed mammal nutrition (especially Capreolus capreolus and Cervus elaphus). The stripped bark dendromass per forested area of $625 \mathrm{~m}^{2}$ reached $3 \mathrm{~m}^{2}$. After the mild winter in 2014, the majority (93.7\%) of previously affected Fraxinus excelsior trees in the forest locality had only old damages with renewed bark in different phases of regeneration. In the non-forest locality, 96\% of young Fraxinus excelsior, damaged in the winter of 2013, shot up new sprouts. The mortality of affected trees was minimal (4-5\%).
\end{abstract}

Key words: hoofed game, bark stripping, European ash, Malé Karpaty Mts.

\section{Introduction}

In the past decades, the landscape has changed significantly. Continuous urbanisation has caused intensive fragmentation of the landscape and conflicts with nature protection. Animals are very good indicators of the degree of changes of environmental conditions by different activities of man (Kalivodová, 1996).

The number of impassable barriers has increased recently; especially, built barriers hinder migration. Fragmentation of biotopes decreases the possibilities of forest animals to obtain food, especially in unfavourable weather conditions. Consequently, ungulates strip trees; these tendencies are especially visible during off-vegetative periods when undergrowth is not sufficient or when the land is covered by snow. Impacts from ungulates on wooden plants were described and studied in many parts of Europe, for example, Great Britain (Gill 
et al., 2000), Czech Republic (Čermák et al., 2004; Malík, Karnet, 2007), Austria (Vospernik, 2006), Germany (Kiffner et al., 2008) Slovenia (Jerina et al., 2008), Slovakia (Rajský et al., 2008), France (Saint-Andrieux et al., 2009) and Serbia (Gačić et al., 2012). Damage of forest growth by hoofed animals is related to foraging ecology and food intake. Foraging ecology was the subject of multiple studies (e.g., Fišer, Lochman, 1969; Bališ, 1980; Findo, Žilinec, 1993; Weisberg, Bugmann, 2003; Prokešová, 2004). The authors clearly imply that woody plants are an important part of hoofed animal diet; in some areas, they constitute 50 to $80 \%$ of the entire diet.

The research was focused on the examination of forest and non-forest stands damages, caused by ungulates on migration routes in the valley of Kučišdorfská dolina, located in Malé Karpaty Mts (SW Slovakia, Fig. 1), on the evaluation of the forms of woody plant damages and phases of bark renewal.

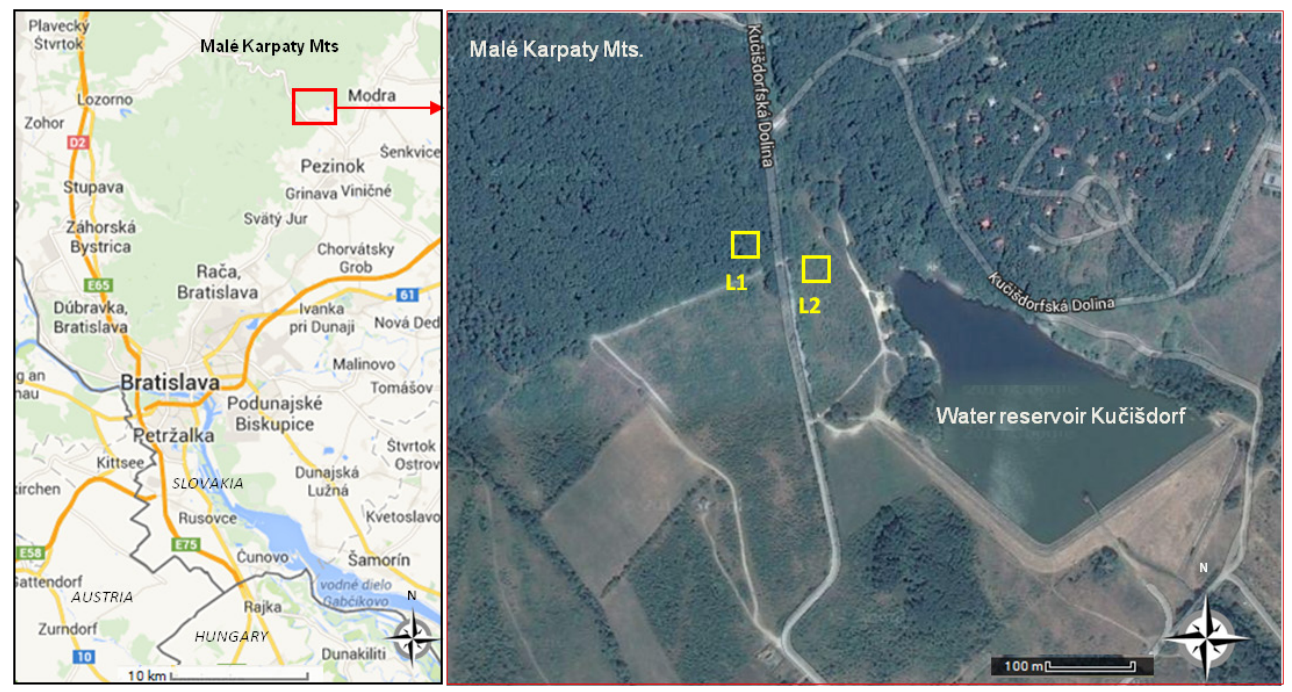

Fig. 1. Location of research localities: L1 - forest locality; L2 - non-forest locality (Google maps 2014, modified).

\section{Material and methods}

Based on direct observations and indirect signs (presence of traces, excrements), the species of forest animals that use the area for migration, foraging and access to water reservoir were identified. In the selected area, the impact from ungulates on wooden plants in April-May 2013 and March 2014 was monitored. Two representative localities were determined: the first locality L1 inside the forest (about $5 \mathrm{~m}$ from the forest edge) and the second locality L2 outside of the forest. These localities were of square shape, each having size $25 \times 25 \mathrm{~m}\left(625 \mathrm{~m}^{2}\right)$.

In the study localities (L1, L2) two different types of damages caused by ungulates were identified: (1) bark stripping and biting around the trunk (Fig. 2) and (2) bitten-off shoots (Fig. 3). In the selected localities, the number of woody plants was registered. In the forest locality, the girth of a tree trunk ( $130 \mathrm{~cm}$ above the ground) was measured. A stripped bark patch was measured and the following parameters were surveyed: localisation of a stripped bark patch on a trunk expressed in its height above the ground, length and width of a stripped bark patch. In the non-forest biotope, the number of damaged woody plants (trees and shrubs) was investigated in the two categories of their height: under $1 \mathrm{~m}$ and above $1 \mathrm{~m}$. Data analyses were oriented on the number of woody species that were encountered by animals 




Fig. 2. Bark stripping of Fraxinus excelsior in the forest locality L1 with/ in detail (photo: Ružičková, 12 April 2013).

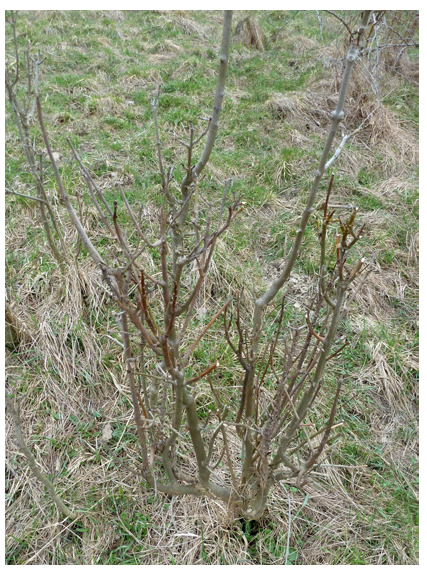

Fig. 3. Bitten-off shoots of Fraxinus excelsior in the non-forest locality L2 (photo: Ružičková, 12 April 2013).

(Cervus elaphus and Capreolus capreolus species) and on the evaluation of bark stripping extent (localisation of bark stripping on the trunk, area of stripped bark patches). On the affected tree trunks teeth marks and also patches of stripped bark were observed. The quantity of stripped bark is expressed to the specified locality area $625 \mathrm{~m}^{2}$.

In spring 2014, damaged trees and shrubs were monitored from the viewpoint of new damages and the state of trees and shrubs. On the locality L1, the extent of bark renewal was recognised as: (1) partly renewed bark at the edges of a stripped patch; (2) mainly renewed bark; and (3) fully renewed bark (Figs 4a, b, c).

On the locality L2, occurrence of new shoots at damaged trees was observed. Nomenclature of plant species is listed according to Marhold and Hindák (1998). Nomenclature of animal species is reported according to Wilson and Reeder (2005).

\section{Study area}

The studied localities L1, L2 are situated on the local migration route from the forest of Malé Karpaty Mts through non-forest biotope to the Kučišdorf water reservoir (Fig. 1), which represents the part of the long distance migration route from Malé Karpaty Mts to forest fragments Šenkvický háj and Martinský les woods at Trnavská pahorkatina upland (Ružičková et al., 2011). The study locality L1, situated in the eastern part of Pezinok cadastral area in Malé Karpaty Mts, is composed of oakhornbeam Carpathian forest (association Querco petraeae-Carpinetum Soó et Pócs (1931) 1957 p. p.). The study locality L2 represents a non-forest community with grassland and scattered trees and shrubs. The Kučišdorf water reservoir, surrounded by alder wood fragments and by grasslands, is used by forest animals as the source of water.

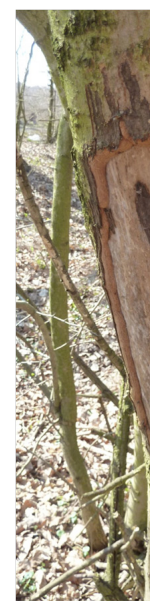

$4 a$

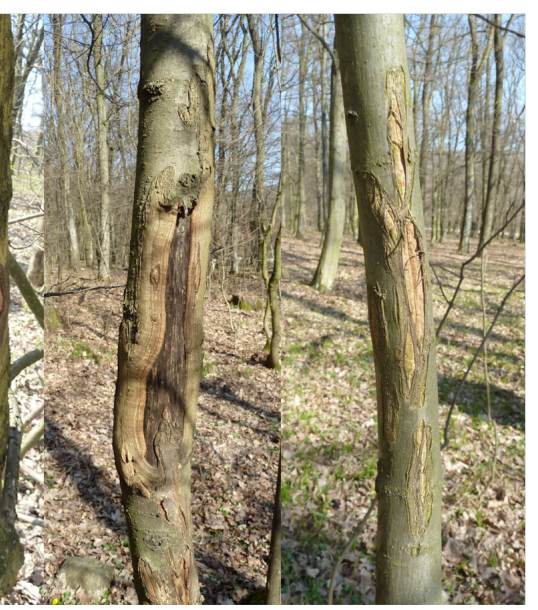

$4 c$
Fig. 4. Bark regeneration phases of Fraxinus excelsior in the forest locality L1: a - partly renewed bark at the edges of a stripped patch; b - mainly renewed bark; c - fully renewed bark (photo: Ružičková, 12 March 2014). 
The research was performed during the springs of 2013 and 2014. Spring 2013 followed after a winter with high snow coverage, lasting till April; mammals used bark as a source of food during unfavourable conditions. At the beginning of April 2013, trees and shrubs were not foliated and bark stripping damage of woody plants was clearly visible (Figs 2, 3). Winter 2012/2013 was in some regions of Slovakia extreme in terms of certain characteristics of meteorological elements. The meteorological station Bratislava-Koliba in Malé Karpaty Mts recorded a total of 148 $\mathrm{cm}$ layer of new snow throughout the winter. The meteorological station recorded higher new snow cover only during two winters - 1969/1970 and 1986/1987 since 1951 (Faško, Švec, 2013). On the contrary, spring 2014 came after winter with minimal snow coverage. According to Faško and Švec (2014), winter 2013/2014 was one of the warmest winters in the history of meteorological measurements in Slovakia. In general, it was the second warmest after the winter of 2006/2007, but it also had several firsts. Combined were two extremes - high temperatures and lack of snow. Winter 2013/2014 had extremely low numbers of Arctic days. Lack of snow cover during the winter was the highest since 1921, when systematic measurements of snow cover in Slovakia started.

\section{Results}

\section{Species composition}

In the forest locality L1 (Fig. 1), situated on the border of an oak-hornbeam forest, tree species Carpinus betulus, Fraxinus excelsior, Quercus petraea and Quercus robur were determined. Other accompanying species were Acer campestre, Aesculus hippocastanum, Cerasus avium, Tilia cordata, Euonymus europaeus and Swida sanguinea. The woody plants belonged to 11 species, including 7 tree species and 4 shrub species (Table 1). In the herbal undergrowth, Melica uniflora prevailed. Also present were Galeopsis pubescens, Galium aparine, Galium odoratum, Geum urbanum, Fraxinus excelsior, Impatiens parviflora, Poa nemoralis, Quercus petraea, Rubus fruticosus agg. and Sambucus nigra. In the study locality L1 near the forest edge, Fraxinus excelsior was present more often than in older oak-hornbeam forest stands. European ash (Fraxinus excelsior) is common throughout much of Europe and is a valuable broadleaved tree due to its ecological characteristics, outstanding wood properties and high economic value (Dobrowolska et al., 2011).

T a b l e 1. The presence of bark stripping and browsing in the locality L1.

\begin{tabular}{|l|l|c|c|c|}
\hline N. & Woody species & N & ST & \%ST \\
\hline 1 & Acer campestre & 33 & 4 & 12 \\
\hline 2 & Aesculus hippocastanum & 3 & 3 & 100 \\
\hline 3 & Carpinus betulus & 10 & 4 & 17 \\
\hline 4 & Cerasus avium & 6 & 1 & 0 \\
\hline 5 & Crateagus monogyna & 3 & 0 & 50 \\
\hline 6 & Crateagus laevigata & 2 & 1 & 0 \\
\hline 7 & Euonymus europaeus & 1 & 0 & 53 \\
\hline 8 & Fraxinus excelsior & 55 & 29 & 0 \\
\hline 9 & Quercus robur & 1 & 0 & 0 \\
\hline 10 & Quercus petraea & 7 & 0 & 34 \\
\hline 11 & Swida sanguinea & $\mathbf{1 2 3}$ & $\mathbf{4 2}$ & 0 \\
\hline
\end{tabular}

Notes: $\mathrm{N}$ - numbers of all evaluated woody plants, ST - number of woody plants, damaged by bark stripping, \%ST - percentage of woody plants, damaged by bark stripping. 
T a b l e 2. The presence of woody plants damaged by bitten-off shoots in the locality L2.

\begin{tabular}{|l|l|c|c|c|c|c|c|c|}
\hline $\mathbf{N}$. & Species & $\mathbf{N}$ & $\mathbf{N}<\mathbf{1}$ & $\mathbf{N B T}<\mathbf{1}$ & $\mathbf{\% N B T}<\mathbf{1}$ & $\mathbf{N}>\mathbf{1}$ & $\mathbf{N B T}>\mathbf{1}$ & $\mathbf{\% N B T}>\mathbf{1}$ \\
\hline 1 & Acer campestre & 29 & 27 & 14 & 52 & 2 & 0 & 0 \\
\hline 2 & Crataegus monogyna & 29 & 7 & 1 & 14 & 22 & 1 & 5 \\
\hline 3 & Fraxinus excelsior & 54 & 47 & 46 & 98 & 7 & 7 & 100 \\
\hline 4 & Prunus cerasifera & 1 & 0 & 0 & 0 & 1 & 1 & 100 \\
\hline 5 & Prunus spinosa & 1 & 1 & 1 & 100 & 0 & 0 & 0 \\
\hline 6 & Pyrus pyraster & 8 & 3 & 1 & 33 & 5 & 0 & 0 \\
\hline 7 & Quercus robur & 5 & 0 & 0 & 0 & 5 & 2 & 40 \\
\hline 8 & Rosa canina & 12 & 4 & 0 & 0 & 8 & 0 & 0 \\
\hline & SUMMARY & $\mathbf{1 3 9}$ & $\mathbf{8 9}$ & $\mathbf{6 3}$ & $\mathbf{7 1}$ & $\mathbf{5 0}$ & $\mathbf{1 1}$ & $\mathbf{2 2}$ \\
\hline
\end{tabular}

Notes: $\mathrm{N}$ - number of all evaluated woody plants, $\mathrm{N}<1-$ number of woody plants lower than $1 \mathrm{~m}, \mathrm{NBT}<1-$ number of bitten-off shoots (BT) damaged woody plants lower than $1 \mathrm{~m}, \% \mathrm{NBT}<1$ - percentage of BT damaged woody plants lower than $1 \mathrm{~m}, \mathrm{~N}>1$ - number of woody plants higher than $1 \mathrm{~m}, \mathrm{NBS}>1$ - number of BT damaged woody plants higher than $1 \mathrm{~m}, \% \mathrm{NBT}>1$ - percentage of BT damaged woody plants higher than $1 \mathrm{~m}$.

The non-forest locality L2 (Fig. 1) was partly (45\%) covered by woody plant species as Crataegus monogyna, Prunus spinosa and Rosa canina. Young trees of Fraxinus excelsior occur often; Quercus robur, Pyrus pyraster, Acer campestre and Prunus cerasifera were also present. The recorded woody plants belonged to 8 species, representing 5 tree species and 3 shrub species (Tables 1,2). The plant layer in the neighbourhood of shrubs and trees was dominated by grass species Alopecurus pratensis, Arrhenatherum elatius and Trisetum flavescens. There were found Achillea millefolium, Allium vineale, Carex hirta, Cirsium arvense, Dactylis glomerata, Galium aparine, Galium verum, Humulus lupulus, Poa pratensis, Ranunculus acris, $R$. sardous, Rubus fruticosus agg., Rumex acetosa, Tithymalus cyparissias, Vicia sativa, Vicia hirsuta and others.

The most common species of ungulates in the study area is Capreolus capreolus. Other common species are Sus scrofa and Cervus elaphus. Non-native species are represented by Ovis aries, occasionally also Dama dama.

By direct observation and according to signs of presence, Capreolus capreolus, Cervus elaphus, Sus scrofa and Lepus europaeus were detected.

The above-mentioned mammal species prefer a diet that is fresh, cellulose rich and albuminous. They browse grass, herbs, wooded shoots, leaves, buds and various forest fruits. Furthermore, they graze agricultural products such as potatoes, beet and oat and winter crops. Economical damages caused by forest game are mainly due to peeling the bark of trees (Ophoven, 2011).

\section{Assesment of ungulates' impact on woody plants in spring 2013}

In the forest locality (L1) bark stripping and biting of tree trunks by Cervus elaphus was distinguished (Fig. 2); in the non-forest locality (L2) mainly biting of leading and lateral shoots of young trees and shrubs by Capreolus capreolus was observed (Fig. 3). The most affected species on both of the studied localities was Fraxinus excelsior (Table 2). European 
ash (Fraxinus excelsior) grows in most parts of Slovakia, frequently in floodplain forests, but also in landslide sites. The bark of the ash is grey-green, smooth, with old trees greyish brown to black, finely furrowed (Úradníček et al., 2009). In the autumn, ash leaves do not change colour, but the green fades. Dried leaves and shoots were used as winter feed for cattle (Úradníček, Chmelař, 1995). In accordance with Saláta et al. (2010), closed forests were more or less used for grazing, acorn forage, cutting tree foliage for fodder and collecting dead fallen leaves in the traditional system of farming. In the Bakony Mts, livestock used to be fed on foliage. The predominant species used for forage feeding was the ash species (Fraxinus sp.).

According to Konôpka et al. (2012), the intensity of grazing of particular parts varies during the year, depending mainly on the phenological phase of a tree and on changes in availability of other food diet. Animals browse on leaves mainly at the end of spring, during the summer and at the beginning of autumn, while shoots are available throughout the year. Conversely, in winter animals feed mainly on branches with buds. Wild animals consume leaves of European ash even after they have fallen down, and sometimes they rip them from the snow.

\section{Forest locality L1}

In the forest locality (L1), 123 woody plants were evaluated, out of which trunks of 42 woody plants (34\%) were stripped and bitten (Table 1) mostly by Cervus elaphus species. European ash (Fraxinus excelsior) was the most injured tree species, of which 29 out of 55 trees (53\%) were damaged. The second most damaged species was hornbeam (Carpinus betulus), of which 4 out of 10 trees (40\%) were stripped and bitten and the third most affected species was field maple (Acer campestre) with 12\% of injured trees ( 4 out of 33 trees). All three individuals of horse chestnut (Aesculus hippocastanum) were marked with bark stripping and biting of shoots. Wild cherry (Cerasus avium) belongs to a less preferred species: out of 6 individuals only 1 was affected. This occurred despite the fact that these were young trees with an average trunk girth of $34 \mathrm{~cm}$.

The average girth of tree trunks of all 123 measured woody plants in the forest locality L1 was $29 \mathrm{~cm}$, with pedunculate oak (Quercus robur) having the largest girth $(203 \mathrm{~cm})$ without stripping. Sessile oak (Quercus petraea) with girth measuring $132 \mathrm{~cm}$ was not stripped. The average girth of non-bark-stripped tree trunks was $33 \mathrm{~cm}$, while the average girth of bark-stripped tree trunks was $20 \mathrm{~cm}$. The highest difference between the girth averages of the tree trunks of bark-stripped and non-bark-stripped individuals was observed in Acer campestre (Fig. 5).

Stripped bark appeared at different heights on trunks. The difference in maximum height was from 60 to $175 \mathrm{~cm}$ over the ground. The average height of the affected bark on tree species was as follows: Fraxinus excelsior $-142 \mathrm{~cm}$, Carpinus betulus $-110 \mathrm{~cm}$ and Acer campestre $-150 \mathrm{~cm}$ above ground.

As the results show, in the forest locality L1, hoofed game preferred younger trees with trunk girth smaller than $59 \mathrm{~cm}$. The most damaged trees were of a girth 4-19 cm (Fig. 6).

The length of stripped bark (measured vertically) varied from 1 to $155 \mathrm{~cm}$. Young ash trees were most affected, while trees growing between thorny species, for example, Rubus fruticosus agg. and Crateagus monogyna remained unharmed. 


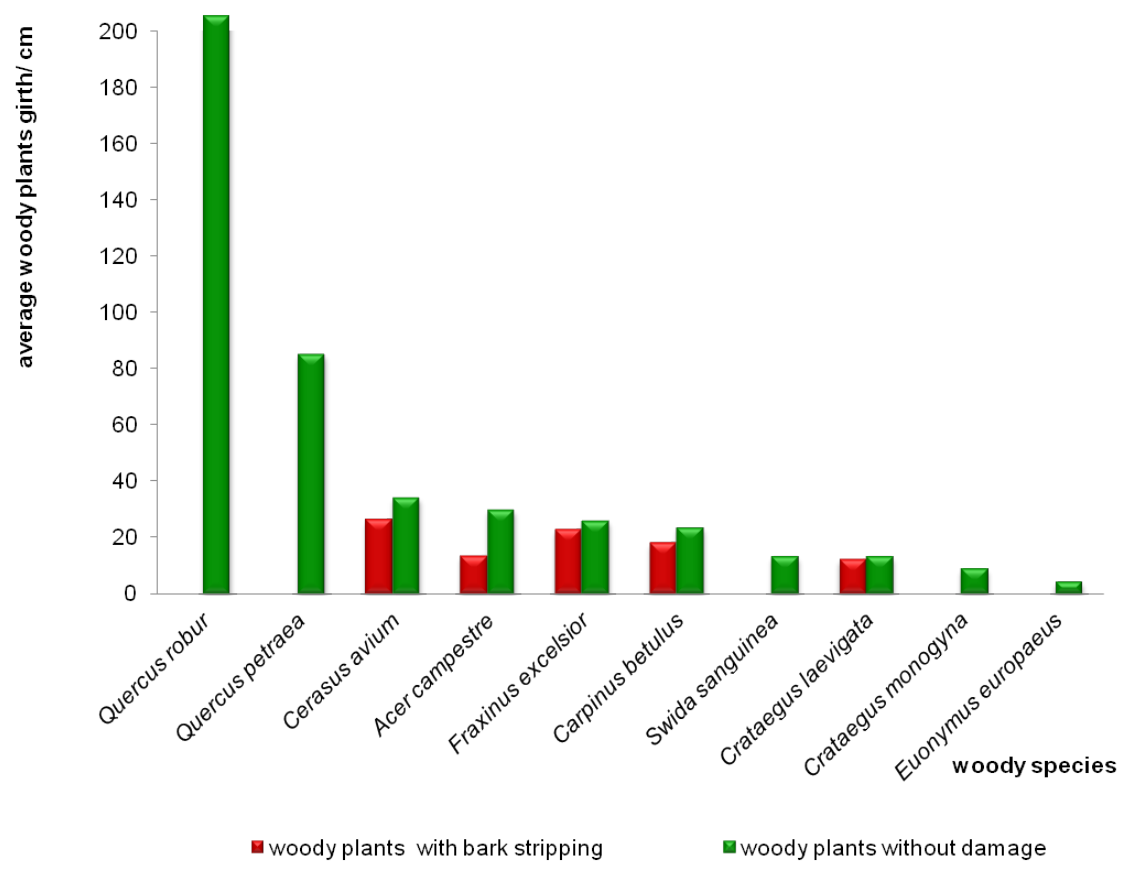

Fig. 5. Occurrences of bark stripping on woody species according to the average girth of tree trunk (locality L1).



Fig. 6. The presence of bark stripping according to the girth interval of tree trunk (locality L1). 
The width of stripped bark (measured horizontally) varied from 0.4 to $28 \mathrm{~cm}$. Some species of Fraxinus excelsior were stripped around the whole trunk. Acer campestre and Carpinus betulus were damaged only on small patches.

The surface of stripped bark in the forest locality L1 was as follows: Fraxinus excelsior $2.952 \mathrm{~m}^{2}$, Acer campestre $-0.025 \mathrm{~m}^{2}$, Carpinus betulus $-0.023 \mathrm{~m}^{2}$ and Cerasus avium -0.002 $\mathrm{m}^{2}$. As the results show, hoofed game preferred Fraxinus excelsior over the other tree species. The stripped dendromass per study area of $625 \mathrm{~m}^{2}$ was $3.002 \mathrm{~m}^{2}$, representing $0.48 \mathrm{~m}^{2}$ stripped dendromass area of $100 \mathrm{~m}^{2}$.

\section{Non-forest locality L2}

In the non-forest locality L2, 139 woody plants were assessed, out of which 74 (53\%) were affected by bitten-off shoots mostly by Capreolus capreolus species. Most affected was Fraxinus excelsior where 53 out of 54 individuals in the study area were marked, especially the tips of leading and side shoots of trees were bitten off (Fig. 3). The second most bitten woody plant in L2 locality was field maple (Acer campestre): 14 (48\%) out of 29 individuals were marked with stripping. Some of the other species, for example, Quercus robur and Rosa canina were present here in smaller numbers and were affected to a lesser extent (Table 2).

Hoofed game obviously preferred younger individuals, smaller than $1 \mathrm{~m}$, where it bit off shoots: $71 \%$ of all woody plants, lower than $1 \mathrm{~m}$, in the locality were strongly affected. Almost $98 \%$ of ash trees with height below $1 \mathrm{~m}$ were bitten off. Regarding woody plants higher than $1 \mathrm{~m}, 22 \%$ of trees were affected by biting off leading and side shoots. In this case, not only the shoots were affected, but sometimes the bark was also stripped, although to a minor extent.

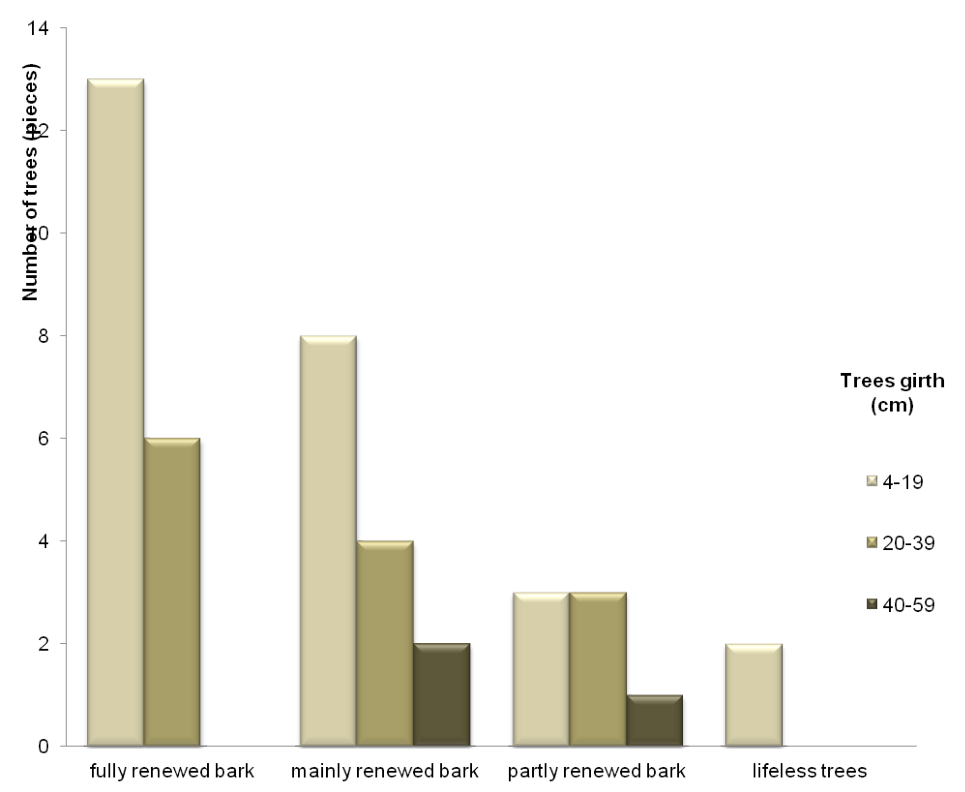

Fig. 7. Bark renewal phases, depending on the tree trunk girth. 


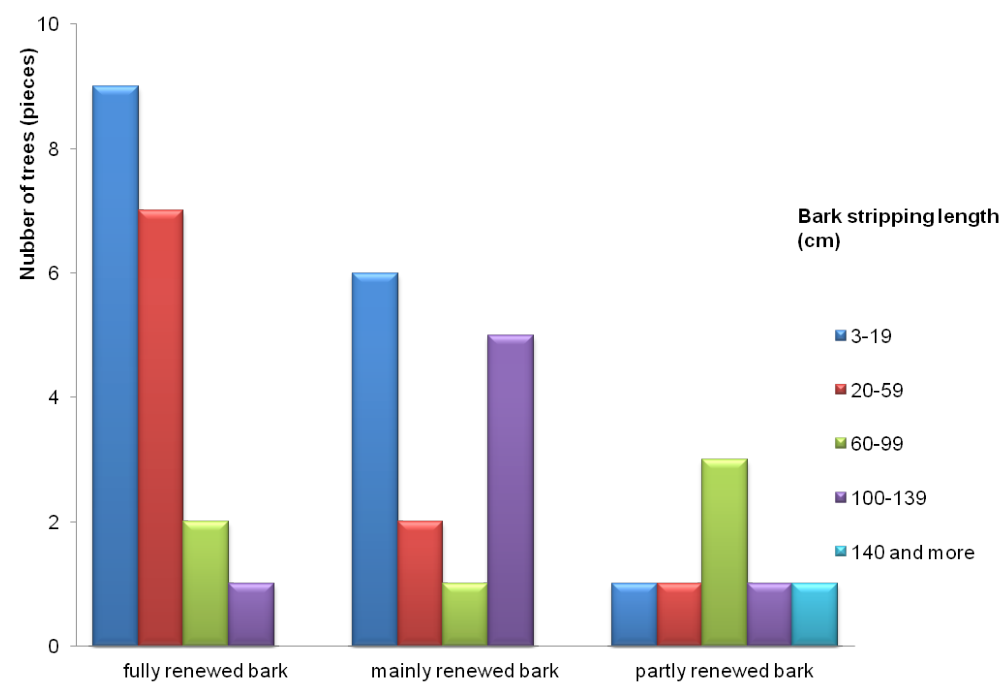

Fig. 8. Bark renewal phases, depending on the length of the stripped bark.

Monitoring of damaged woody plants in spring 2014

The winter of 2014 was very warm; temperatures were higher than in the winter of 2013 and snow cover lasted only a few days. In the forest locality (L1) trees and shrubs were monitored, new bark damage was not found, but regeneration of bark in different phases was recognised. Among 42 trees, affected in the winter of 2013, fully renewed bark was observed in 19 trees (45.2\%), mainly renewed bark was found at 14 trees (33.3\%), partly renewed bark at the edge of the affected patch started at 6 trees and 1 shrub $(16.7 \%)$ and 2 young ash trees $(4.8 \%)$ were lifeless. Bark regeneration phase was evaluated depending on the tree trunk girth and the length of stripped bark (Figs 7,8). The quickest regeneration was observed, as expected, in younger, less affected trees. From the viewpoint of plant species, 4 field maple trees (Acer campestre), 3 hornbeam trees (Carpinus betulus) and 1 wild cherry tree (Cerasus avium) in the study area were fully renewed. In one representative of shrubs, midland hawthorn (Crataegus laevigata), bark renewal at the edge was observed.

Among 32 European ash trees (Fraxinus excelsior), fully renewed bark was observed in 11 trees $(34.4 \%)$, mainly renewed bark was found on 13 trees $(40.6 \%)$, partly renewed bark at the edge of the affected patch (Fig. 9) started at 6 trees (18.8\%) and 2 young ash trees $(6.3 \%)$ were lifeless.

In the non-forest locality (L2) 74 woody plants, affected in the winter of 2013, were observed. Out of 74 trees none was newly stripped. Ninety-six percent of young trees, strongly damaged during the winter of 2013, sprouted new shoots. Only 3 young trees of Fraxinus excelsior (4\%) damaged by biting off terminal and lateral shoots were lifeless. 


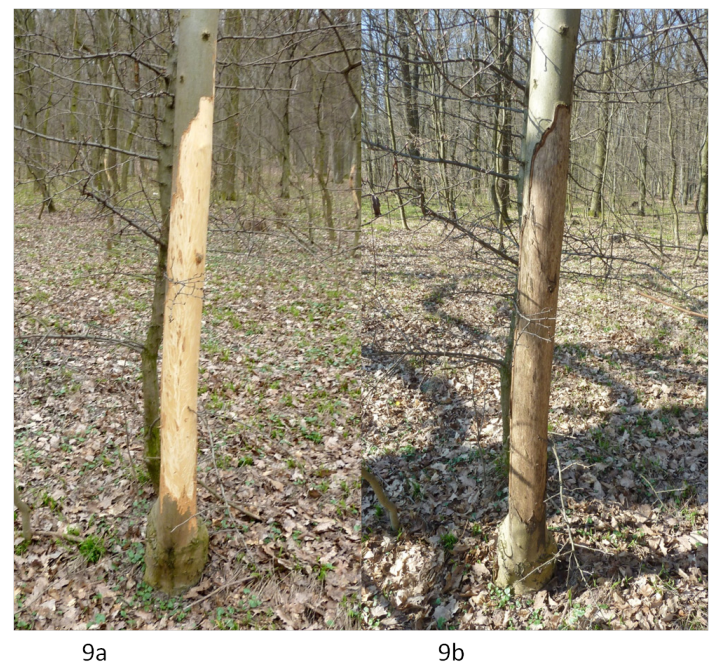

Fig. 9. Fraxinus excelsior damage and regeneration: a - stripped bark after a long and cold winter 2012/2013 (photo: Ružičková, 12 April 2013); b - Fraxinus excelsior bark renewal, starting from the edge of a stripped patch after the warm winter of 2013/2014 (photo: Ružičková, 12 March 2014).

\section{Discussion}

According to Mrkva (2001) damage by bark stripping occurs mainly when foraging niche is depleted (locally or seasonally). Then, more physically able deer use the last opportunity, which are branches and bark. Different woody plant species may be affected, but the spruce is most preferred. Usually, ruminant, even-hoofed mammals (native species: Cervus elaphus, Capreolus capreolus; introduced species: Ovis musimon, Cervus nippon and Dama dama) consume shoots of woody plants, and bushes or leaves of some herbs and occasionally grasses.

In the study area in the valley of Kučišdorfská dolina in Malé Karpaty Mts, oak-hornbeam forest prevails. Dominant tree species are Quercus petraea agg. and Carpinus betulus. An-

other present accessory species is Fraxinus excelsior whose bark constitutes an essential part of hoofed mammals' diet during the extra-vegetative period and is preferred to other woody plants. Konôpka et al. (2012) states that animals damaged ash trees with a diameter of less than $20 \mathrm{~mm}$ (height up to $1.6 \mathrm{~m}$ ) solely by biting off branches. Conversely, for individuals with a diameter above $45 \mathrm{~mm}$ (height cca $4.6 \mathrm{~m}$ ), bark stripping prevails. Deer bite off branches mainly at a height from 41 to $160 \mathrm{~cm}$. Damage by bark stripping could be found at $180 \mathrm{~cm}$. Estimates of biomass foraged (expressed as dried matter) in ash coppice were from a few kilograms to $21.4 \mathrm{~kg}$ per $100 \mathrm{~m}^{2}$ of a stand area. An important factor in the quantification of stripped bark is the height and diameter of trees. The results obtained by the above-mentioned authors reveal that dendromass of young ashes foraged by hoofed mammals represents a significant amount of their diet chiefly in the winter period.

In the studied localities the results were very similar; bitten-off young shoots and branches of Fraxinus excelsior were observed most frequently on trees with a height below $1 \mathrm{~m}$ and with a trunk girth up to $4 \mathrm{~cm}$. Bark stripping was present most often in trees with an average trunk girth of $20.6 \mathrm{~cm}$. Stripping appeared on the tree trunks of Fraxinus excelsior at average height $142 \mathrm{~cm}$; the amount of scoffed bark dendromass of Fraxinus excelsior was 2.952 to $625 \mathrm{~m}^{2}$ of the area being examined, representing 0.48 to $100 \mathrm{~m}^{2}$. Ungulates did not strip thorny woody plants, except one exemplar Crataegus laevigata in the forest locality and two exemplars of Crataegus monogyna (one lower than $1 \mathrm{~m}$ and one higher than $1 \mathrm{~m}$ ) in the non-forest locality.

Krojerová-Prokešová et al. (2009) states that Rubus fruticosus, belonging to a species with thorns, can be an important part of deer's diet. The authors performed the research in a 
floodplain forest. Leafy woody plants were the most important part of the diet for roe deer (Capreolus capreolus) during the whole year except the period April-May. During that period Rubus fruticosus was consumed in the same amount as woody plants.

Kunca et al. (2010) states that European ash is endangered especially by two damaging factors at present: fungus Chalara fraxinea and ruminant hoofed mammals. Both damaging factors impact chiefly young forest growth. This fact is also confirmed by research in forest and non-forest localities in Malé Karpaty Mts (the valley of Kučišdorfská dolina), where Fraxinus excelsior is the most suffering tree species by stripping of bark and biting off young shoots.

Findo (2010) documented that deer negatively affect the survival of young European ash trees in Slovakia. While younger stands at the initial stage of growth contained $1.8 \%$ of European ash trees, older stages contained only $0.6 \%$. Using his own measurements, the author found that $60 \%$ of European ash trees are damaged at the initial stages of growth.

The results from the spring of 2014 have shown that in favourable conditions Fraxinus excelsior and other species (e.g., Acer campestre, Carpinus betulus) are able to regenerate very well. In the forest area L1, 30 trees (93.7\%) of Fraxinus excelsior, damaged in the winter of 2013, had only old damage of bark from the previous year with renewed bark in different phases of regeneration. In the non-forest locality (L2), 74 trees had new shoots. Only three Fraxinus excelsior trees were lifeless.

The development of natural regeneration is limited by trophic preferences of game and by the tolerance of particular species to repeated damage (Čermák, Mrkva, 2006).

Bark stripping represents emergency winter forage and only occurs in areas with high red deer (Cervus elaphus) densities and during winters when deep snowfalls restrict the range of animal movement. Although bark stripping is a very selective form of damage, it does not jeopardise the survival of trees and only represents a major problem where stands have a strong productive or protective function (Motta, 1996).

According to Rajsky et al. (2007), the bark stripping of forest-tree species is a natural expression of animal food ecology. In central Europe, the frequency of hoofed mammals has significantly increased in the last few decades and pressure due to the forest environment is higher too. At present, numerous meadows and pastures are unmanaged; the succession is the consequence of destruction of these areas and animals are losing their food sources. The presence of pastures, small fields and fructiferous woody plants improves food resources for animals. Through the year, roe deer (Capreolus capreolus) search for energetically richer food; in the winter, roe deer bite off tree ring termini, frequently only buds in young woods. Roe deer bite off only $1-3 \mathrm{~cm}$ from the end of a twig according to the type of wooden species. In localities with blackberry, the occurrence of bark stripping is lower, blackberries are available for animals all year round, roe deer consume blackberry leaves also through the winter and daily food averages are higher.

In the non-forest locality L2, 139 woody plants were evaluated, out of which $53 \%$ were affected by biting off shoots, mainly by roe deer. The most affected was Fraxinus excelsior where 53 out of 54 individuals in the study area were marked with multiple bitten-off tops and lateral shoots of trees. The second most bitten woody plant in the L2 locality was field maple (Acer campestre). In the non-forest locality most of the trees were bitten by roe deer.

Bark regeneration and tannin content were observed in Myracrodruon urundeuva Allemão after simulation of extractive damages - implications to management was the aim of research of 
Monteiro et al. (2011). Twenty individuals from the area of Caatinga in Caruaru, Pernambuco State (NE Brazil), were selected. To evaluate the speed of bark regeneration, four treatments were established, according to the area/size of bark removed $(10 \times 2,6 \times 5,8 \times 5$ and $10 \times 5 \mathrm{~cm})$, with five replicates (five individuals of Myracrodruon urundeuva Allemão) and three treatments of tannin content (bark removed before damage, as regenerated tissue, and non-impacted bark or control). At the end of 23 months of monitoring the regeneration, it was found that only 7 of the 20 individuals analysed did not fully heal. No significant correlation between the monthly percentage of regeneration and the average monthly precipitation was found.

Regeneration of bark in different phases was recognised in our research area. The quickest regeneration was observed as expected, in younger, less affected trees.

Kiffner et al. (2008) examined the probability of bark stripping of the susceptible Norway spruce (Picea abies) during winter in relation to local environmental characteristics in the western Harz Mountains, Lower Saxony, Germany. The authors present the results of a multiple logistic regression model for recent bark stripping damage by red deer (Cervus elaphus), which was developed from two systematic cluster sampling inventories after two winter periods along with associated meteorological data and records of bagged deer. The model suggests that the risk of bark stripping increased significantly $(\mathrm{P}<0.05)$ with rising slope angle, accumulating snow depth and increasing index values of red deer population density. Tested variables (altitude, length of daily solar irradiation, duration of snow cover, age of spruce stand within the age range of 16-50 years) had no significant effect on the probability of new bark stripping. They conclude that red deer in the western Harz Mountains seem to use bark as a food resource at preferred locations and in times of low food availability.

Also, our research shows that during unfavourable winter condition both species of Cervus elaphus and Capreolus capreolus used bark as the food resource, and bark stripping damage is visible on trees and shrubs.

Bark stripping damage by red deer in the fenced rearing centre 'Lomnička Reka' (Mt. Veliki Jastrebac, central Serbia) was the aim of research by Gačić et al. (2012). The data were collected by a detailed survey of the entire rearing centre over spring and autumn 2008, 2009 and 2010. Their results show that in spring and summer, it is exclusively broadleaf tree species that are bark stripped by red deer, mainly beech ( $86.3 \%$ or 536 trees) and hornbeam ( $10.1 \%$ or 63 trees). The incidence and intensity of bark stripping were the highest in the diameter class of $20-39.9 \mathrm{~cm}$. Damaged trees were identified in all parts of the rearing centre, in all aspects and at different slopes.

Our results show that in the forest locality, hoofed game preferred younger trees with a trunk girth smaller than $59 \mathrm{~cm}$. The most damaged trees were of a girth 4-19 cm. In Malé Karpaty Mts area European ash (Fraxinus excelsior) was the most stripped tree species (53\%), the second most affected species was hornbeam (Carpinus betulus) (40\%) and the third most affected species was field maple (Acer campestre) with $12 \%$ of stripped trees.

\section{Conclusion}

The aim of the study was to examine the diet potential of woody plants in the migration route: forest-non-forest area with scattered trees and shrubs-water reservoir, to compare the damage by bark stripping of woody plants in forest and non-forest localities and to evaluate 
the types of tree damages by hoofed game. In the forest locality, ungulates preferred younger trees with a trunk girth up to $59 \mathrm{~cm}$ for stripping the bark of trunks. In the non-forest locality, dominated by self-seeding woody species, young shoots and branches of trees and shrubs were most exploited. In both selected localities in 2013, European ash (Fraxinus excelsior) suffered from bark stripping by forest animals the most after a cold and long winter. From the other tree species, Acer campestre and Carpinus betulus were damaged the most. In 2014, in both selected localities no specimens of woody plants were stripped and, especially, Fraxinus excelsior trees regenerate very well (93.7 \%) after a hot winter. The presented results imply that woody plants in the migration route in the study area constitute a significant share of the diet of hoofed mammals, mainly during a long winter period.

\section{Acknowledgements}

The research was realised with the support of the grant project VEGA No. 1/1139/11: Changes of landscape connectivity in the contact zone of Malé Karpaty Mts and adjacent lowlands - CONNECA. The authors thank to Dr. Jarmila Cihová, $\mathrm{PhD}$ and Canadian lecturer Michael Sabo for their help with the English language.

\section{References}

Bališ, M. (1980). Red deer (in Slovak). Bratislava: Príroda.

Čermák P., Glogar, J. \& Jankovský L. (2004). Damage by deer barking and browsing and subsequent rots in Norway spruce stands of Forest Range Mořkov, Forest District Frenštát p. R. (the Beskids Protected Landscape Area). J. For. Sci., 50(1), 24-30.

Čermák, P. \& Mrkva R. (2006). Effects of game on the condition and development of natural regeneration in the National Nature Reserve Vrapač (Litovelské Pomoraví). J. For. Sci., 52(7), 329-336.

Dobrowolska, D., Hein, S., Oosterbaan, A., Wagner, S., Clark, J. \& Skovsgaard J.P. (2011). A review of European ash (Fraxinus excelsior L.): implications for silviculture. Forestry - an International Journal of Forest Research, 84(2), 133-148. DOI: 10.1093/forestry/cpr001.

Faško, P. \& Švec M. (2013). Temperature, precipitation and snow conditions in winter 2012-2013 (in Slovak). Bratislava: SHMÚ. http://www.shmu.sk/sk/?page=2049\&id=414

Faško, P. \& Švec M. (2014). Oversized warm winter 2013-2014 (in Slovak). Bratislava: SHMÚ. http://www.shmu.sk/ sk $/$ ?page $=2049 \&$ id $=515$

Find'o, S. \& Žilinec M. (1993). Effect of simulated winter bite to the development of some forestry important woody species (in Slovak). Folia Venatoria, 23, 37-50.

Findo, S. (2010). Factors influencing red deer damages of mountain forests in Nízke Tatry (Low Tatras) Mts (in Slovak). In B. Konôpka (Ed.), Výskum smrečín destabilizovaných škodlivými činitelmi (pp. 187- 197). Zvolen: NLC.

Fišer, Z. \& Lochman J. (1969). The results of studies of red deer and roe deer natural food (in Czech). In Huntsmanship - hoofed game (pp. 17-31). Proceedings of the National Conference. České Budějovice: Dům techniky CSVTS.

Gačić, P.D., Danilović, M., Zubić, G. \& Ćirović P. (2012). Bark stripping damage by red deer (Cervus elaphus L.) in the fenced rearing centre Lomnička reka. Bulletin of the Faculty of Forestry, 105, 35-50. DOI: 10.2298/GSF1205035G.

Gill, R., Webber, J. \& Peace A. (2000). The economic implications of deer damage - A review of current evidence. (pp. 1-49). Final Report for the Deer Commission for Scotland, Forest Research Agency, Surrey.

Jerina, K., Dajčman, M. \& Adamič M. (2008). Red deer (Cervus elaphus) bark stripping on spruce with regard to spatial distribution of supplemental feeding places. Zbornik Gozdarstva in Lesarstva, 86, 33-43.

Kalivodová, E. (1996). Fauna as the limiting factor of anthropic activities (in Slovak). Acta Environmentalica Universitatis Comenianae (Bratislava), 7, 65-68.

Kiffner, C., Rössiger, E., Trisl, O., Schulz, R. \& Rühe F. (2008). Probability of recent bark stripping damage by red deer (Cervus elaphus) on Norway spruce (Picea abies) in a low mountain range in Germany - a preliminary analysis. Silva Fenn., 42, 125-134. DOI: 10.14214/sf.269. 
Konôpka, B., Pajtík, J., Kaštier, P. \& Šebeň V. (2012). Determination of young ash tree dendromass eaten by red deer using allometric models (in Slovak). Zprávy Lesníckého Výzkumu, 57(3), 283-294.

Krojerová-Prokešová, J., Barančeková, M. \& Homolka M. (2009). Importance of floodplain forests for the management of red deer and roe deer (in Slovak). Folia Venatoria, 38-39, 17-25.

Kunca, A., Konôpka, B., Malová, M. \& Ivanič L'. (2010). Analysis of mostly deep-going disasters from 1996 year accordance data of Forest Protection Service (in Slovak). In B. Konôpka (Ed.), Výskum smrečín destabilizovaných škodlivými činitelmi (pp. 107-116). Zvolen: Národné lesnícke centrum.

Malík, V. \& Karnet P. (2007). Game damage to forest trees. J. For. Sci., 53(9), 406-412.

Marhold, K. \& Hindák F. (Eds.) (1998). Checklist of non-vascular and vascular plants of Slovakia. Bratislava: Veda.

Monteiro, J.M., Lins-Neto, E.M.F., Araujo, E.L., Amorim, E.L.C. \& Albuquerque U.P. (2011). Bark regeneration and tannin content in Myracrodruon urundeuva Allemão after simulation of extractive damages-implications to management. Environ. Monit. Assess., 180, 31-39. DOI: 10.1007/s10661-010-1770-3.

Motta, R. (1996). Impact of wild ungulates on forest regeneration and tree composition of mountain forests in the Western Italian Alps. For. Ecol. Manag., 88, 93-98. DOI: 10.1016/S0378-1127(96)03814-5.

Mrkva, R. (2001). Damages through peeling and gnawing of red deer are on increase (in Czech). Lesnická Práce, 80(4), 164-167.

Ophoven, E. (2011). Fair game, biology, characters, hunting methods (in Slovak). Bratislava: Slovart.

Prokešová, J. (2004). Red deer in the floodplain forests: the browse specialist? Folia Zool., 53, 293-302.

Rajský, M., Hell, P., Vodňanský, M. \& Garaj M. (2007). Toward biological protection forward of damages by animals - part 1 (in Slovak). Lesník, 1, 16-17. http://www.cvzv.sk/ziv/Rajsky6.pdf

Rajský, M., Vodňanský, M., Hell, P., Slamečka, J., Kropil, R. \& Rajský D. (2008). Influence supplementary feeding on bark browsing by red deer (Cervus elaphus) under experimental conditions. European Journal of Wildlife Research, 54, 701-708. DOI: 10.1007/s10344-008-0199-2.

Ružičková, J., Lehotská, B., Ďugová, O., Gombiková, Z., Haceková, Z., Janitor, A., Kalivodová, E., Moravčíková, Z., Nevřelová, M. \& Petrovič F. (2011). Selected terrestrial biocorridors and biocenters in the contact zone of Trnavská pahorkatina upland and Malé Karpaty Mountains (in Slovak). Bratislava: Univerzita Komenského.

Saint-Andrieux, C., Bonenfant, C., Toïgo, C., Basille, M. \& Klein F. (2009). Factors affecting beech Fagus sylvatica bark stripping by red deer (Cervus elaphus) in a mixed forest. Wildl. Biol., 15, 187-196. DOI: 10.2981/07-100.

Saláta, D., Penksza, K., Malatinszky, A. \& Kenéz Á. (2010). Facts to the landscape history of the Öreg-Bakony Mountains. Tájökológiai Lapok, Special Issue, 79-88.

Úradníček, L. \& Chmelař J. (1995). Forest dendrology - part II. (in Czech). Brno: Mendelova Univerzita.

Úradníček, L., Maděra, P., Tichá, S. \& Koblížek J. (2009). Woody plants in Czech Republic (in Czech). Brno: Mendelova Univerzita.

Vospernik, S. (2006). Probability of bark stripping damage by red deer (Cervus elaphus) in Austria. Silva Fenn., 40, 589-601. DOI: 10.14214/sf.316.

Weisberg, P.J. \& Bugmann H. (2003). Forest dynamics and ungulate herbivory: from leaf to landscape. For. Ecol. Manag., 181, 1-12. DOI: 10.1016/S0378-1127(03)00123-3.

Wilson, D.E. \& Reeder D.M. (Eds.) (2005). Mammal species of the world: a taxonomic and geographic reference. Baltimore: The Johns Hopkins University Press. 